\title{
A new Late-glacial and Holocene record of vegetation and fire history from Lago del Greppo, northern Apennines, Italy
}

\author{
Elisa Vescovi • Brigitta Ammann • Cesare Ravazzi • \\ Willy Tinner
}

Received: 15 July 2009/Accepted: 1 February 2010/Published online: 22 April 2010

(C) Springer-Verlag 2010

\begin{abstract}
Detailed Late-glacial and Holocene palaeoenvironmental records from the northern Apennines with a robust chronology are still rare, though the region has been regarded as a main area of potential refugia of important trees such as Picea abies and Abies alba. We present a new high-resolution pollen and stomata record from Lago del Greppo (1,442 m a.s.1., Pistoia, northern Apennines) that has been dated relying on 12 terrestrial plant macrofossils. Late-glacial woodlands became established before 13000 cal B.P. and were dominated by Pinus and Betula, although more thermophilous taxa such as Quercus, Tilia and Ulmus were already present in the Greppo area, probably at lower altitudes. Abies and Picea expanded locally at the onset of the Holocene at ca. $11500 \mathrm{cal}$ B.P. Fagus sylvatica was the last important tree to expand at ca. 6500 cal B.P., following the decline of Abies. Human impact was generally low throughout the Holocene, and the local woods remained rather closed until the most recent time, ca. A.D. 1700-1800. The vegetational history of Lago del Greppo appears consistent with that of previous investigations in the study region. Late-glacial and Holocene vegetation dynamics in the northern Apennines are very similar to those in the Insubrian southern Alps bordering Switzerland and Italy, across the Po Plain. Similarities between the
\end{abstract}

Communicated by H.-J. Beug.

E. Vescovi $(\bowtie) \cdot$ B. Ammann $\cdot$ W. Tinner

Institute of Plant Sciences and Oeschger Centre for Climate

Change Research, University of Bern, Altenbergrain 21, 3013

Bern, Switzerland

e-mail: elisa.vescovi@ips.unibe.ch

E. Vescovi · C. Ravazzi

C.N.R., Institute for the Environmental Dynamics, via Pasubio 5

I, 24044 Dalmine, Italy two areas include the Late-glacial presence of Abies alba, its strong dominance during the Holocene across different vegetation belts from the lowlands to high elevations, as well as its final fire and human-triggered reduction during the mid Holocene. Our new data suggest that isolated and minor Picea abies populations survived the Late-glacial in the foothills of the northern Apennines and that at the onset of the Holocene they moved upwards, reaching the site of Lago del Greppo. Today stands of Picea abies occur only in two small areas in the highest part of the northern Apennines, and they have become extinct elsewhere. Given the forecast global warming, these relict Picea abies stands of the northern Apennines, which have a history of at least 13,000 years, appear severely endangered.

Keywords Northern Apennines · Late-glacial . Holocene $\cdot$ Pollen analysis · Abies alba $\cdot$ Picea abies

\section{Introduction}

In general, well-preserved and continuous lake sediment or mire sequences are uncommon in the northern Apennines (Lowe 1992). Many natural archives have been modified or destroyed by recent intensive human activities, so complete Late-glacial and Holocene sequences are rare in the study region. Glacial/Late-glacial records are generally sparse (Lagdei I and II, Berceto and Prato Spilla; Bertoldi 1980; Lowe 1992; Bertoldi et al. 2007). Most sites cover only parts of the Holocene and at some of these sites sediment started to accumulate only from the mid Holocene onwards. The few pollen diagrams published before the 1980s lack fundamental information such as ${ }^{14} \mathrm{C}$ dates, high temporal and taxonomic resolution (Chiarugi 1936a, b, 1958; Braggio Morucchio and Guido 1975; Braggio Morucchio et al. 1978, 
1980; Bertoldi 1980). More recent studies provide valuable information (Cruise 1990a, b; Lowe 1992; Lowe and Watson 1993; Mori Secci 1996; Watson et al. 1994; Watson 1996), but high resolution records combined with ${ }^{14} \mathrm{C}$ dates on terrestrial plant macrofossils are still very rare.

The insufficient number of palaeoenvironmental study sites in the Apennines is scientifically critical. Since the pioneer investigations by Chiarugi (1936a, b, 1958), the northern Apennines have been regarded as an area of potential refugia of one of the most valuable trees in Europe, Picea abies, which reaches its southernmost limit for Italy in this part of the Apennines. Different hypotheses have been proposed about the role played by these populations in the recolonization routes after the last glaciation, and genetic analyses have been carried out to try to define the existence of possible refugia (Scotti et al. 2000; Vendramin et al. 2000), some of them considering the isolated spruce populations in the Apennines (Tollefsrud et al. 2008). The aim of this paper is to present a new pollen record from Lago del Greppo (1,442 m a.s.l., Valle del Sestaione, northern Apennines), which may contribute to a better understanding the past vegetational dynamics in the northern Apennines. This new information about the past may also help to clarify the present distribution and ecological potential of Picea abies and other important taxa such as Abies alba in this region of southern Europe.

\section{Study area and study site}

The northern Apennines are a mountainous region covering parts of Liguria, Emilia-Romagna and Toscana. The mountain chain has a prevalent northwest to southeast trend and the highest peaks exceed 2,000 m, such as Monte Cimone (2,163 $\mathrm{m}$ a.s.l.). The geology ranges from late Cretaceous to late Tertiary and is dominated by limestones, sandstones and shales, but ophiolites and igneous rocks are also present in the western part of the region. The Apennine watershed separating central and northern Italy was glaciated, and shows a number of glacial cirques on the northward Emilian slope down to 1,000 m a.s.l., with only small patches of former glacial activity on the southern Tyrrhenian side (Jaurand 1998).

Lago del Greppo $\left(44^{\circ} 07^{\prime} 11^{\prime \prime} \mathrm{N}-10^{\circ} 40^{\prime} 67^{\prime \prime} \mathrm{E}, 1,442 \mathrm{~m}\right.$ a.s.l.) is located on the northern slope of Monte Poggione in the high Valle del Sestaione in the province of Pistoia, Toscana, near Passo dell'Abetone (Fig. 1a, b). It is a small and shallow pond, ca. $7 \mathrm{~m}$ by ca. $2.5 \mathrm{~m}$, situated on a small level area on the northern slope of Monte Poggione, ca. $3 \mathrm{~km}$ east of Alpe Tre Potenze. There is a fen on the southwestern shore of the pond (Fig. 1c). The basin has no evident inlet or outlet. The origin of the pond is not clear, but it probably originated from a landslide (De Stefani 1883), though glacial cirques occur close by, on the

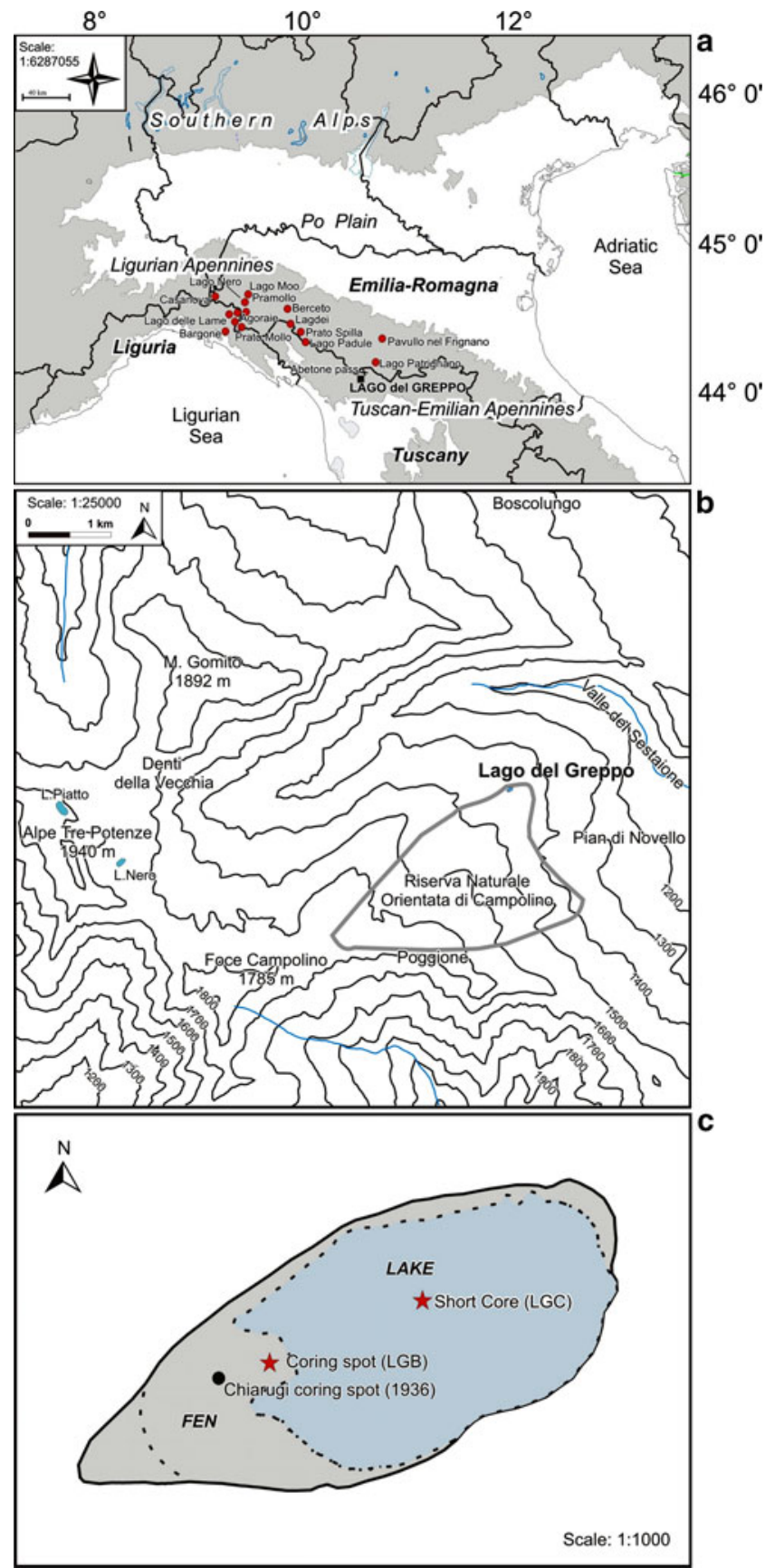

Fig. 1 a Location of important sites mentioned in the present paper; b simplified map of the Lago del Greppo area; c the lake and coring spot, modified following Chiarugi (1936a, b)

northeast slope of Alpe Tre Potenze. The bedrock is rather homogeneous and mainly consists of the Macigno Formation, middle-upper Oligocene/lower Miocene sandstone with thin layers of clay and silty clay.

The present climate regime is cool temperate. This part of the northern Apennines is reached by cold continental winds on the Emilian slope, and by mild winds on the Toscana side (Pinna 1977). Mean annual, mean July and mean January air temperatures are $6.7,15-16$, and $-2.1^{\circ} \mathrm{C}$, 
respectively, according to records from the Station of Abetone-Boscolungo at 1,340 $\mathrm{m}$ a.s.l., ca. $2 \mathrm{~km}$ away from Lago del Greppo. Average annual precipitation is 2,520 $\mathrm{mm}$, with a maximum in November.

In Valle del Sestaione the woodland is dominated by Fagus sylvatica and Abies alba at altitudes between 900 and 1,800 $\mathrm{m}$ a.s.l., while Picea abies occurs only in the highest part of the valley with sporadic stands below $1,600 \mathrm{~m}$ a.s.l., and trees near the divide. Today, the lake is surrounded by woods dominated by Fagus sylvatica, Abies alba and Picea abies. Acer pseudoplatanus, Sorbus aucuparia, S. aria, Laburnum alpinus and Vaccinium myrtillus are present as well, emphasising the cool-temperate character of these mountain-belt woods.

\section{Materials and methods}

Coring, sediments and dating

In September 2003 two parallel cores $20 \mathrm{~cm}$ apart, LGA and LGB, were taken in the fen in the southwestern part of Lago del Greppo with a modified Streif-Livingstone piston corer (Merkt and Streif 1970). We reached a maximum depth of $350 \mathrm{~cm}$ and the core LGB was used for analysis in this study. A short core $56 \mathrm{~cm}$ long was taken from the centre of the lake
(LGC, Fig. 1c). The cores from the fen and from the lake were correlated at a depth of $52 \mathrm{~cm}$ on the basis of radiocarbon chronology and bio-stratigraphic correlation.

Sediment components were measured quantitatively by loss-on-ignition (LOI) following the procedure described by Heiri et al. (2001). One $\mathrm{cm}^{3}$ of wet sediment was dried overnight at $105^{\circ} \mathrm{C}$, then burned for $4 \mathrm{~h}$ at $550^{\circ} \mathrm{C}$ and, in a second step, for $2 \mathrm{~h}$ at $950^{\circ} \mathrm{C}$. The LOI of the sediment was calculated as the percentage dry weight after each ignition (Fig. 2).

Accelerator Mass Spectrometry (AMS) radiocarbon dates were obtained from terrestrial plant macroremains measured at the Poznan Radiocarbon Laboratory, Poland. The ${ }^{14} \mathrm{C}$ dates were calibrated as calendar years before present (cal B.P.) with the program CALIB 5.0.1 (Reimer et al. 2004). The depth-age model was developed with a weighted mixed-effect regression model within the framework of generalised additive modelling (Heegaard et al. 2005) to derive the simplest model (Fig. 2). An extrapolation below the oldest radiocarbon date is not attempted because of lithological changes.

\section{Pollen and charcoal analysis}

Samples of $1 \mathrm{~cm}^{3}$ were prepared for pollen and microscopic charcoal analysis according to standard methodology including HF and acetolysis (Moore et al. 1991).
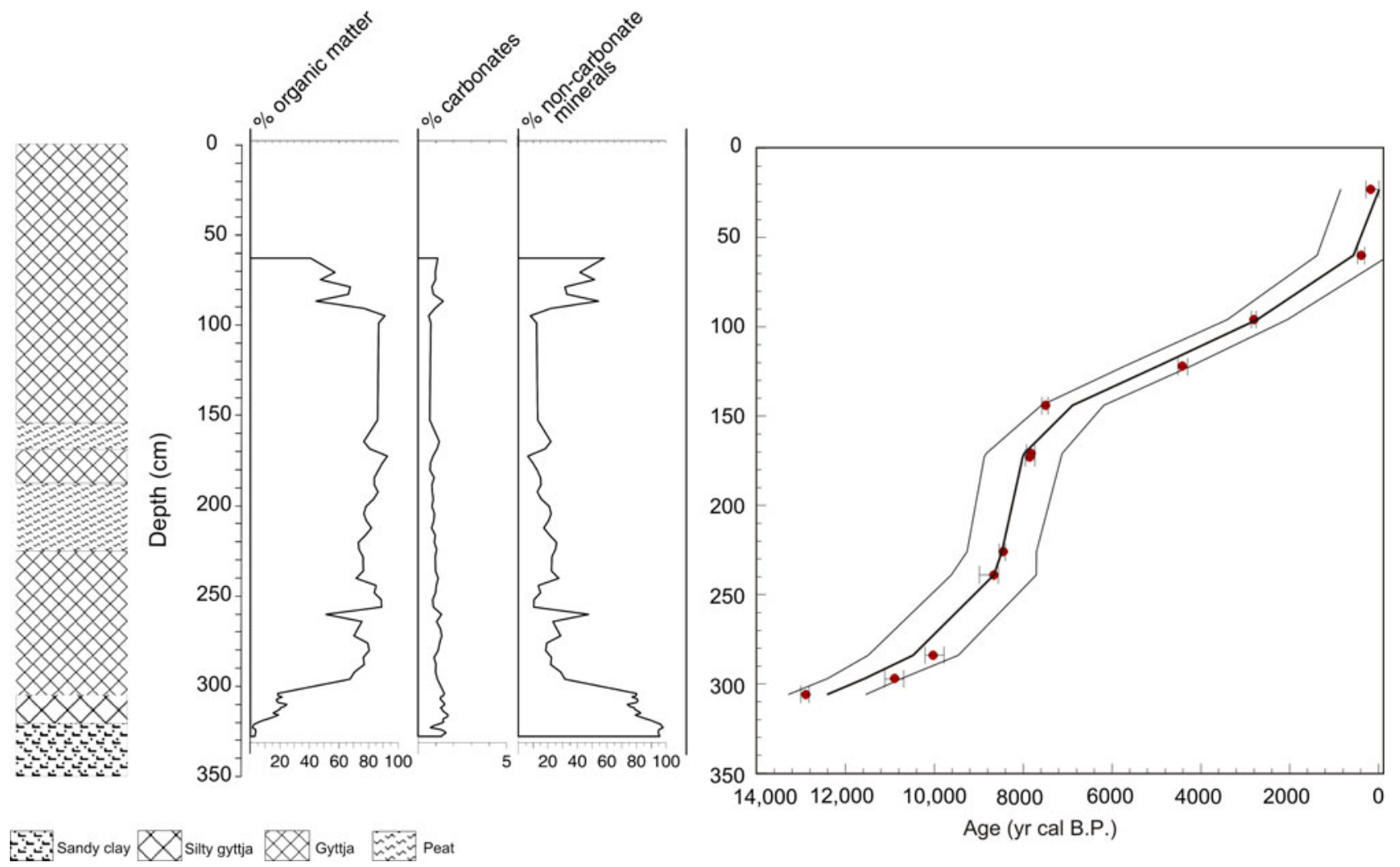

Fig. 2 Lithostratigraphy, loss on ignition and depth/age models for Lago del Greppo 
Lycopodium tablets were added to the sediments samples for estimation of pollen concentrations in grains $/ \mathrm{cm}^{3}$ (Stockmarr 1971). The prepared samples were stored in glycerine. For each sample a sum of more than 600 pollen grains excluding Cyperaceae, aquatics and spores was counted and identified with the use of the reference collection of the Institute of Plant Sciences at the University of Bern, as well as keys and atlases (Punt and Blackmore 1976-2003; Moore et al. 1991; Reille 1992-1998; Beug 2004). Nomenclature of pollen types follows Moore et al. (1991) and Beug (2004). Identification of stomata follows Trautmann (1953). Pollen diagrams were drawn with the programs TILIA 1.12 and TiliaGraph 2.12. The results are presented as TGView 2.0.2 pollen diagrams (Figs. 3, 4; Grimm 1992-2005). To determine local pollen assemblage zones, numerical zonation was carried out with optimal sum of square partition (Birks and Gordon 1985). SSPZ (limits of statistically significant pollen zones) were determined by the broken-stick model (Bennett 1996). Microscopic charcoal particles longer than $10 \mu \mathrm{m}$ were identified and counted in the pollen slides following Tinner and $\mathrm{Hu}$ (2003) and Finsinger and Tinner (2005). Particle concentrations as charcoal particles $\mathrm{cm}^{-3}$ were estimated with the same approach as for pollen.
Numerical methods

Rarefaction analysis was used to estimate pollen diversity (Fig. 5), a proxy for past biodiversity (Birks and Line 1992; Odgaard 1999). Preliminary DCA (detrended correspondence analysis) on the data-set was used to estimate the gradient lengths of the underlying latent variables (Hill 1979). Because the length of the first DCA was more than two standard deviations, DCA was used to extract the major underlying gradient. The results of preliminary DCAs are shown in Fig. 5.

\section{Results and interpretation}

Chronology, lithology and loss on ignition

The radiocarbon dates are given in Table 1 . All ${ }^{14} \mathrm{C}$ dates were accepted. The sediments from Lago del Greppo consist of clay and sand from the core base $(350 \mathrm{~cm})$ up to $320 \mathrm{~cm}$, followed by silty gyttja (304 to $320 \mathrm{~cm}$ ), gyttja and peat. Several layers of wood occur from ca. $270 \mathrm{~cm}$ depth to the top of the core. Loss on ignition analysis shows that organic content first increases slightly at $320 \mathrm{~cm}$ and then abruptly

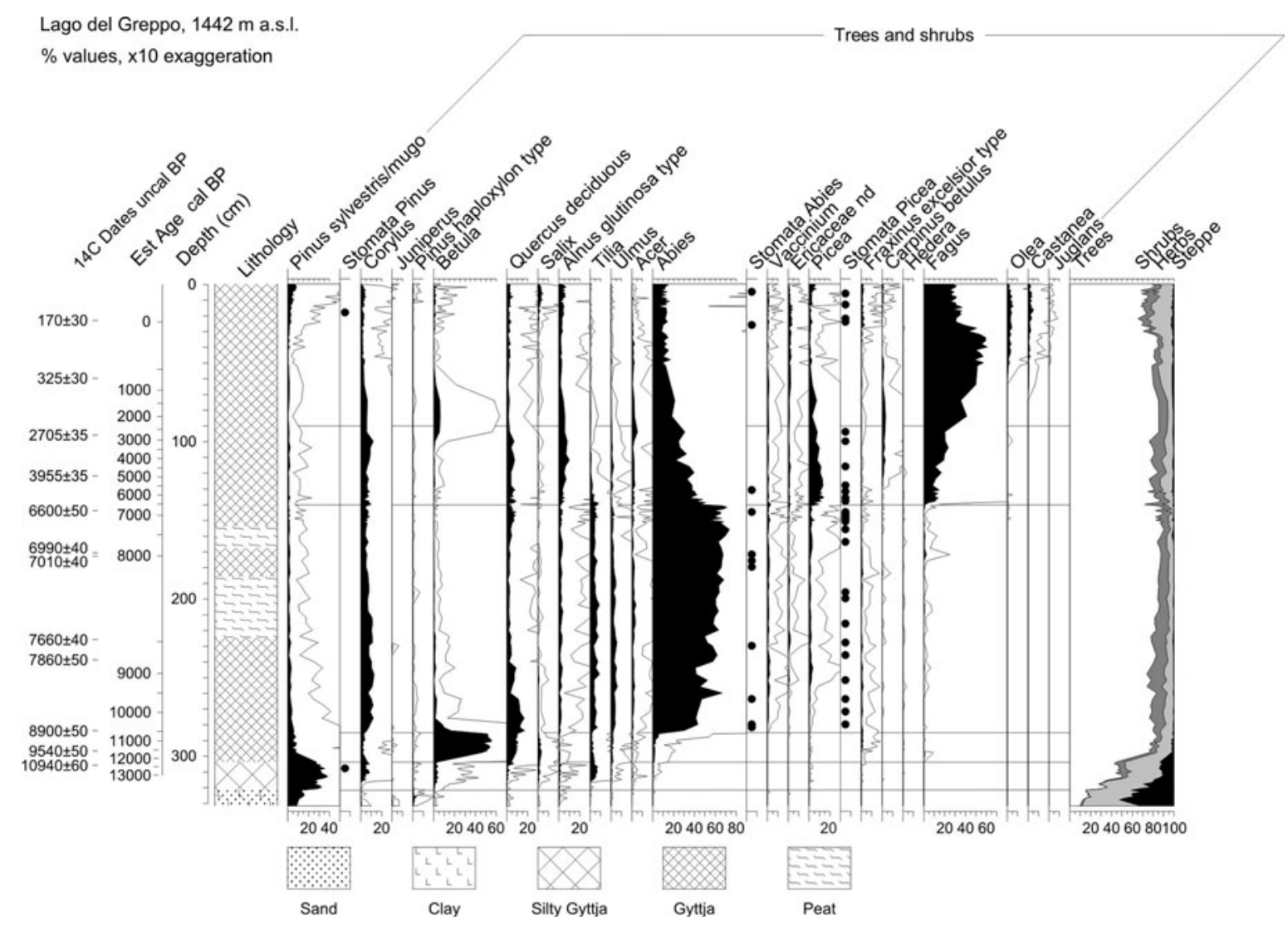

Fig. 3 Late-glacial and Holocene percentage pollen diagram of selected pollen taxa, stomata and charcoal (exaggeration $\times 10)$ from Lago del Greppo (LGB, LGC) 
between 304 and $295 \mathrm{~cm}$ (Fig. 2). The content of organic matter maintains values around $80 \%$ with some oscillations until $100 \mathrm{~cm}$, where they drop abruptly. Carbonates are almost absent (Fig. 2). Therefore, the non-carbonate minerogenic content shows an opposite pattern of abundance compared with the organic matter. The most prominent peat layer is dated at ca. $8400-8100 \mathrm{cal}$ в.P., suggesting a substantial lowering of lake level during this time.

\section{Vegetation history at Lago del Greppo}

The diagram can be subdivided into six statistically significant local pollen assemblage zones (LPAZ) LG 1-6 (Fig. 3 and Table 2). The pollen data suggest that in zone LG-1, until ca. 13500-14000 cal в.P., the landscape around Lago del Greppo was open, characterized by a pioneer vegetation typical of a cold steppe environment with Artemisia, Chenopodiaceae, Gramineae, Anthemis and Aster type. Shrubs such as Juniperus and Ephedra were perhaps also present. Between ca. 13500 and 13000 cal B.P. during the first part of LG-2, high pollen percentages of Pinus sylvestris/mugo occur, but the absence of stomata may suggest transport of pollen from the lowlands. In the second part of LG-2, Betula fruits and Pinus stomata indicate that around $13000 \mathrm{cal}$ в.P. birch and pine were growing around the site, together with Juniperus and other shrubs. The first weak increase to very low percentages and a closed continuous curve of Abies pollen, in the middle of zone LG-2, suggests a first local expansion of fir in the Greppo area, confirmed by the finding of Abies needles at ca. $304 \mathrm{~cm}$ (ca. 13000 cal B.P. during the Bølling-Allerød period, corresponding to Greenland Interstadial GI-1a see Vescovi et al. 2007). The slight increase of Abies pollen coincides with the first regular occurrence of pollen of Corylus, Quercus, Salix, Tilia and Ulmus, suggesting that these more thermophilous taxa also expanded in the region at ca. $13000 \mathrm{cal}$ B.P., probably at lower altitudes. The presence of an almost closed Picea pollen curve, which may indicate the existence of spruce stands in the area of the lake, is also significant.

The beginning of the following zone LG-3 (ca. 12000 11000 cal в.P.) is marked by a Betula peak, corresponding to a weak decrease of rather thermophilous taxa such as Alnus, Corylus and Ulmus, which may suggest a short expansion of light-demanding trees. At the onset of the Holocene at ca. $11500 \mathrm{cal}$ в.P., Abies populations expanded rapidly (zone LG-4, ca. 11000-6500 cal B.P.). Pollen, stomata, and a large quantity of wood, branches, cones and needles unambiguously show that between ca. 10700 and

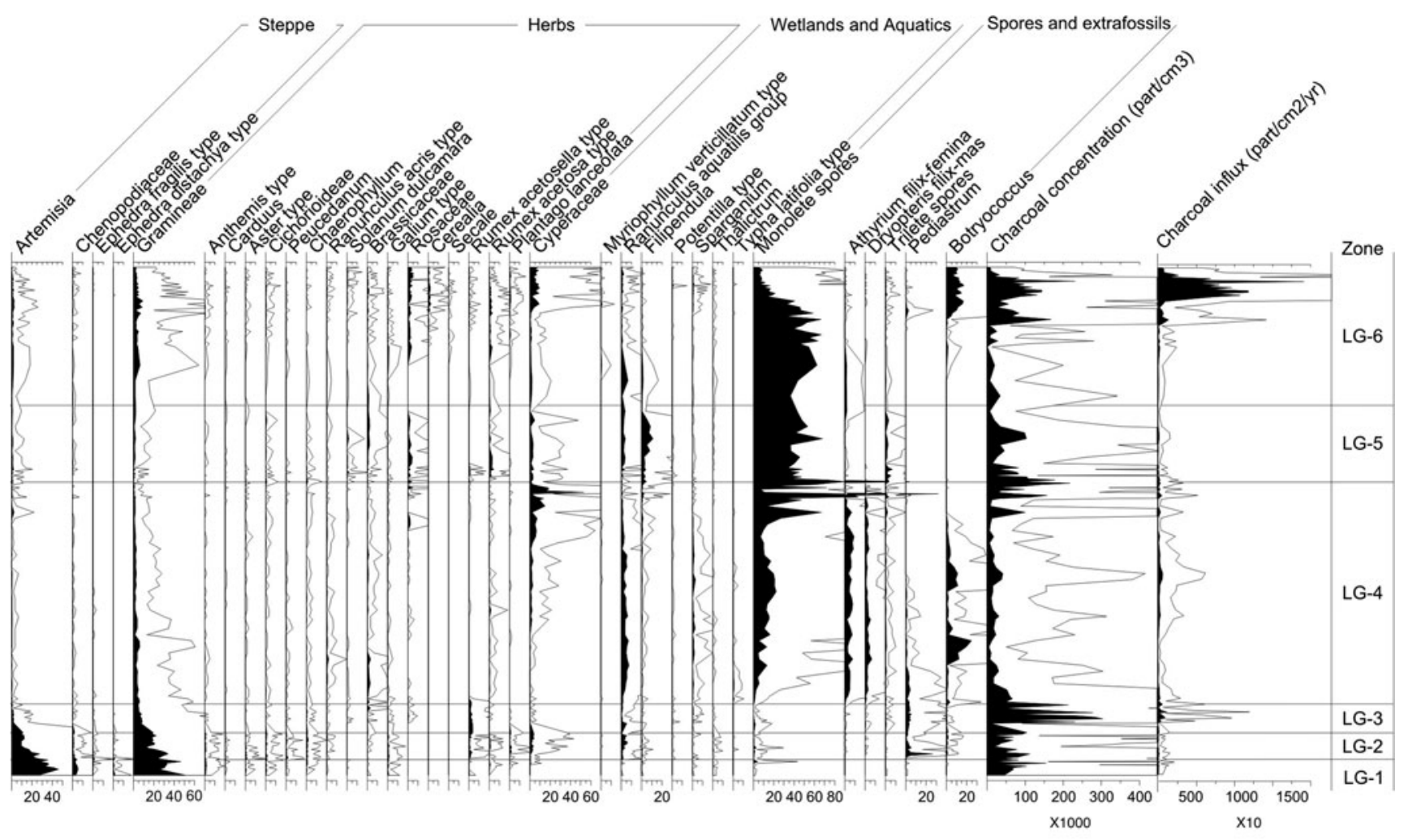

Analysis: E. Vescovi

Fig. 3 continued 
6500 cal B.P., Abies dominated the woodlands around the lake. Also from ca. $10700 \mathrm{cal}$ B.P., Picea stomata and needles indicate the presence of stands of spruce in the area. The vegetation remained rather stable until ca. 6500 cal B.P., when Abies pollen percentages show a first abrupt drop, followed by a gradual decrease. At the beginning of zone LG-5 (ca. 6500-2200 cal B.P.) pollen of Fagus and Picea increase shortly after the decline of Abies. The long lasting Abies decrease is followed by a weak rise in the pollen percentages of Betula, Quercus, Alnus and Carpinus as well as a weak decrease of Tilia and Ulmus. The concomitant decline of Abies, along with a series of peaks in the charcoal concentrations (see charcoal results), suggest that fire was used for clearance of previously undisturbed fir forests. Despite the decline of Abies and the expansion of Fagus, the forest remained very dense and almost stable (zones LG-5 and LG-6) between ca. 2200 cal B.P. to the present. Olea, Castanea and Juglans appear in the pollen record around 1500 cal B.P., indicating the cultivation of these trees at lower altitudes. At ca. 250 cal B.P. (A.D. 1700-1800) Fagus declines, with an increase of Pinus, Corylus, Betula and non-arboreal pollen, probably related to recent human activities.
Floristic diversity

Figure 5 shows that the pollen diversity (pollen sum $=618$ ) did not fluctuate markedly but maintained relatively high values between 30 and 40. Pollen diversity seems to follow largely the non-arboreal pollen (NAP) curve but initially increases during the period when the woods became closed between ca. 13000 and $11500 \mathrm{cal}$ B.P. During the most recent time of vegetation opening in the last 2,000 years, the values increase. Nevertheless, the closed forests show high values of diversity considering the small size of the basin, thus probably indicating a high floristic diversity of local vegetation.

Regional fire history

The Lago del Greppo microscopic charcoal record suggests pronounced changes in regional fire history. Regional fire activity reached maximum levels at around 11500, 6500 and 0 cal B.P., with peaks of $>150,000$ particles $/ \mathrm{cm}^{3}$ (Fig. 3). High concentrations at the onset of the Holocene and at 6500 cal B.P. are influenced by low sedimentation rates. Influx values show that fire activity during modern

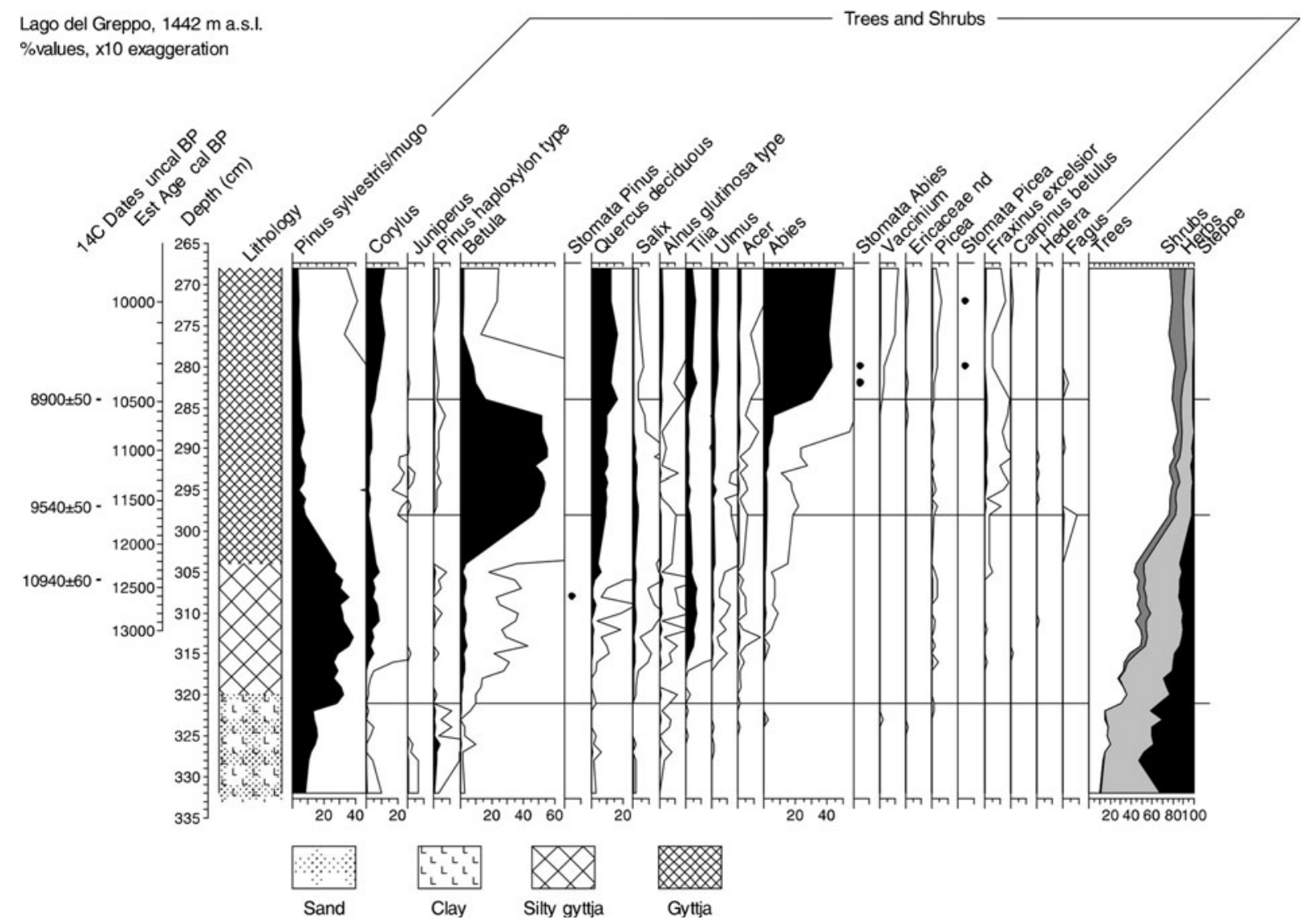

Fig. 4 Late-glacial detail of the percentage pollen diagram of selected pollen taxa, stomata and charcoal (exaggeration $\times 10)$ from Lago del Greppo (LGB) 
time was much higher than during the rest of the Holocene. Nevertheless, the maxima at around 11500 and $6500 \mathrm{cal}$ B.P. are also recorded in microscopic charcoal influx, reaching values of $>500$ particles $/ \mathrm{cm}^{2} / \mathrm{yr}$, or $0.2 \mathrm{~mm}^{2} / \mathrm{cm}^{2}$ / $\mathrm{yr}$ according to the Origlio equation (Tinner and $\mathrm{Hu} 2003$ ). A charcoal peak exceeding 500 particles $/ \mathrm{cm}^{2} / \mathrm{yr}$ also appears around 8200 cal B.P., but it is not prominent in concentration, so it might be partly explicable by changing sedimentation environments with the substitution of gyttja by peat. However, charcoal influx values around 500 are very low and suggest only minor to moderate regional fire activities in the Greppo area before modern times.

\section{Discussion}

Vegetation and fire history, links to climate

\section{Bфlling-Aller $\phi d$ interstadial}

At the onset of the Bølling-Allerød interstadial ca. $14600 \mathrm{cal}$ B.P. (Heiri and Millet 2005; Vescovi et al. 2007) temperatures increased, causing marked vegetation changes that included an upwards migration of the treeline by about 800-900 $\mathrm{m}$ in northern Italy (Tinner and Vescovi 2007). However, the lowlands below $800 \mathrm{~m}$ a.s.l. were already wooded before that time, and in some sheltered parts of northern Italy mixed deciduous-conifer woods persisted there even during the Last Glacial Maximum (LGM) (Kaltenrieder et al. 2009).

It is difficult to assess whether the Late-glacial vegetational succession of Lago del Greppo, beginning at 1400013000 cal B.P. during the Bølling-Allerød interstadial, shows a typical pattern for the northern Apennines, because Late-glacial and early Holocene sediments have not been preserved at many sites in this region, or if preserved they are often interrupted by hiatuses. Previous authors attributed this lack of records to dry conditions in the region during this period (Ponel and Lowe 1992; Lowe and Watson 1993). Only three sites in the northern Apennines, all located in the Appennino Parmense, have Late-glacial successions: Lagdei, Berceto (Bertoldi 1980; Bertoldi et al. 2004, 2007) and the group of basins of Prato Spilla (Lowe 1992; Lowe and Watson 1993).

The Lagdei record probably covers more than the last stadial-interstadial cycle, but it is interrupted by a series of

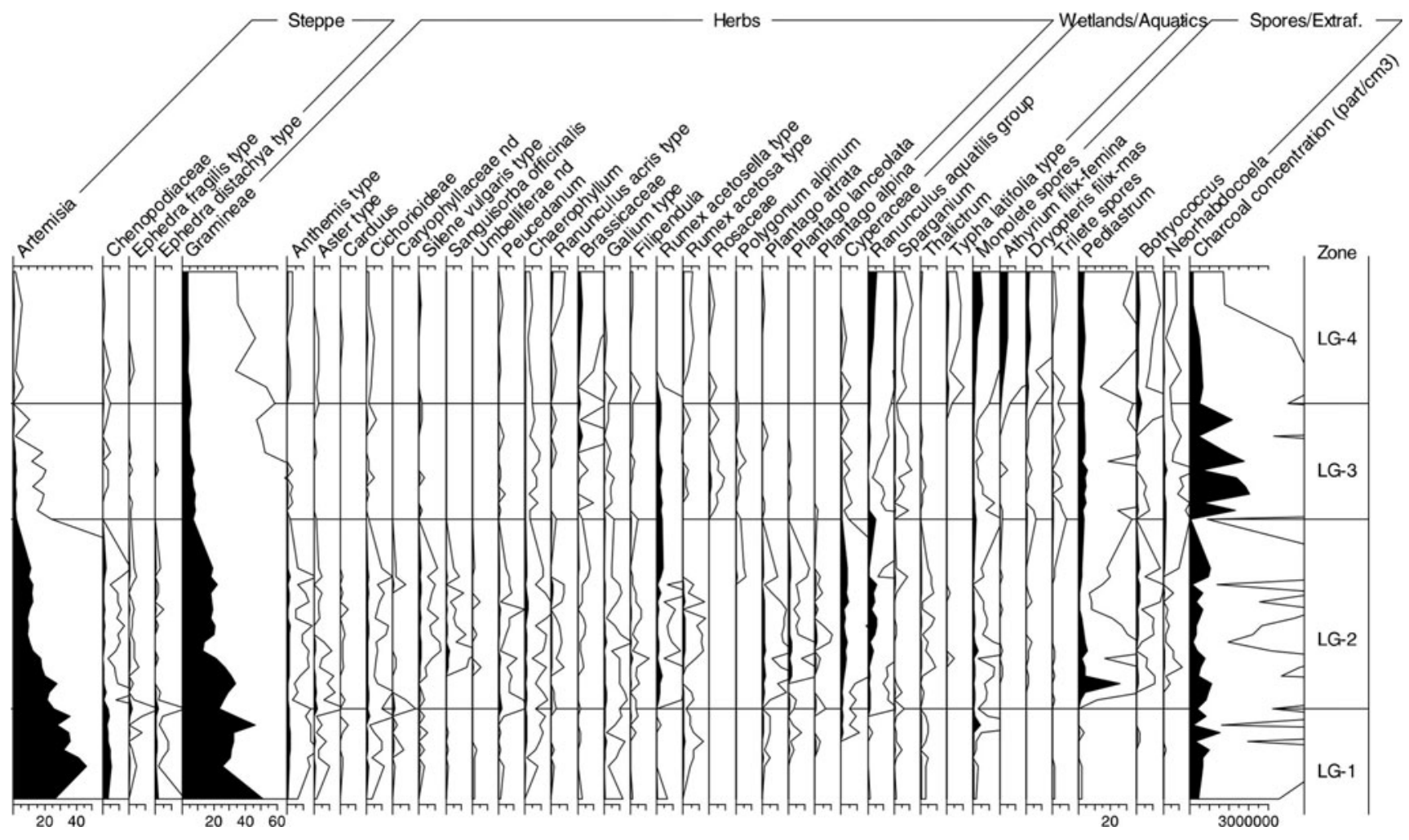

Fig. 4 continued 
Fig. 5 Percentage values of selected taxa (cumulative curves and Abies), pollen diversity and scores of the first and second DCA axes for pollen

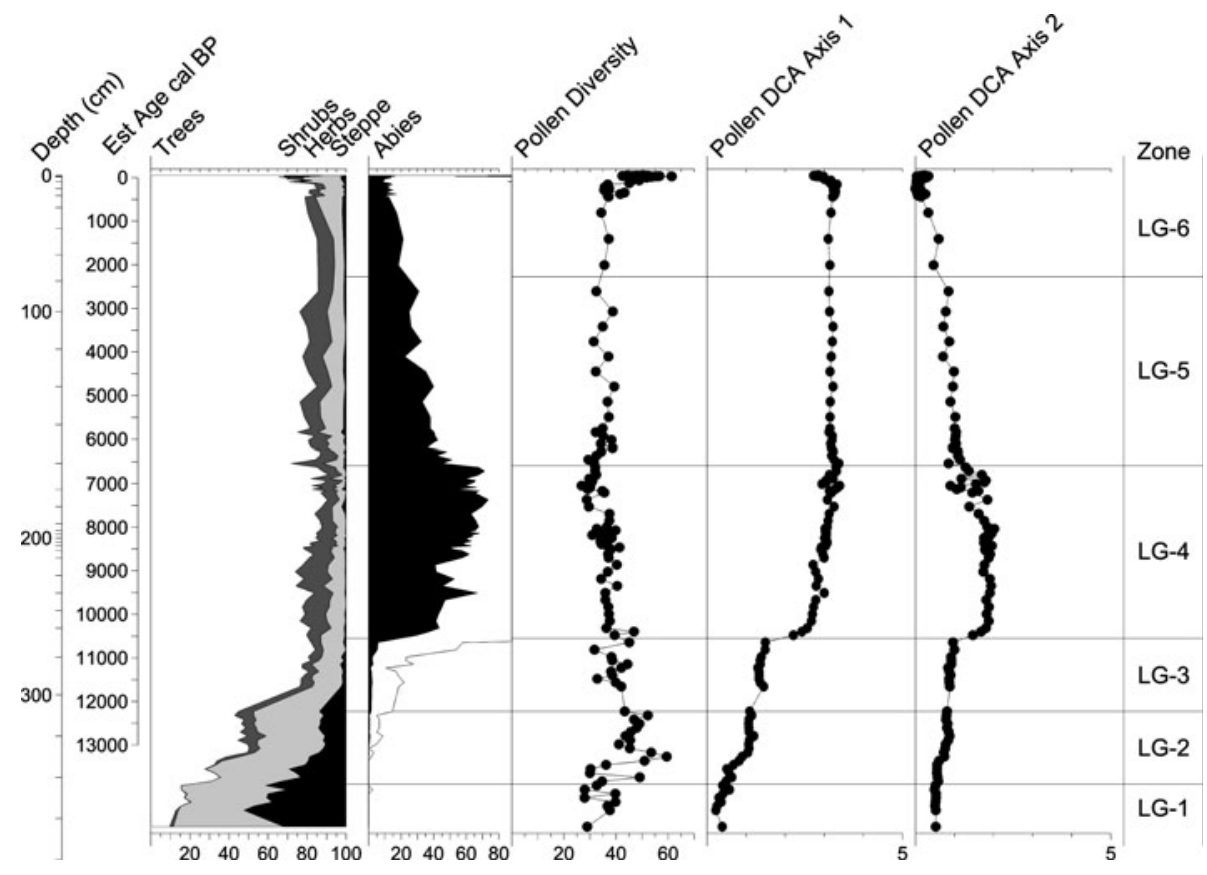

Table 1 AMS radiocarbon dates from Lago del Greppo

\begin{tabular}{llllrrr}
\hline Lab nr & Depth $(\mathrm{cm})$ & Core & Analysed fraction & ${ }^{14}$ C yrs B.P. & Est. age (age cal B.P.) & $\begin{array}{c}\text { Age in diagram } \\
\text { (age cal B.P.) }\end{array}$ \\
\hline Poz-9851 & 23 & LGC & cone scale of Abies & $170 \pm 30$ & -884 to 856 & -14 \\
Poz-6511 & 60 & LGB & Twig of shrub & $325 \pm 30$ & -254 to 1387 & 566 \\
Poz-9849 & 96 & LGB & Abies needles & $2705 \pm 35$ & 2055 to 3405 & 2730 \\
Poz-11173 & 122 & LGB & Needles of Abies & $3955 \pm 35$ & 4220 to 5714 & 4967 \\
Poz-9922 & 144 & LGB & Cone scale and needles of Abies & $6600 \pm 50$ & 6186 to 7592 & 6889 \\
Poz-6515 & 171 & LGB & Needles of Abies & $6990 \pm 40$ & 7121 to 8829 & 7975 \\
Poz-6510 & 173 & LGB & Needles of Abies & $7010 \pm 40$ & 7146 to 8877 & 8012 \\
Poz-6516 & 226 & LGB & Needles of Abies & $7660 \pm 40$ & 7703 to 9262 & 8482 \\
Poz-6517 & 239 & LGB & Needles of Abies & $7860 \pm 50$ & 7709 to 9617 & 8663 \\
Poz-6518 & 284 & LGB & Needles of Abies & $8900 \pm 50$ & 9462 to 11493 & 10478 \\
Poz-19114 & 297 & LGB & Twig of shrub & $9540 \pm 50$ & 10733 to 12395 & 11564 \\
Poz-6520 & 306 & LGB & Needles of Juniperus & $10940 \pm 60$ & 11542 to 13287 & 12415 \\
\hline
\end{tabular}

hiatuses and only the upper part of the sequence has radiocarbon dates (on bulk material probably of peat) spanning from ca. 13000 to $7500 \mathrm{cal}$ B.P. The Berceto sequence is a lacustrine succession representing the infill of a landslide trench (Bertoldi et al. 2004, 2007), and dated between ca. $30000 \mathrm{cal}$ B.P. and the beginning of the Holocene.

The Prato Spilla complex (Prato Spilla A, C and D) is represented by a series of ancient lakes and peat bogs located on moraine ridges (Lowe 1992; Lowe and Watson 1993). These sites have ${ }^{14} \mathrm{C}$ dates on bulk peat and organic mud/gyttja and provide reliable pollen sequences that currently constitute a basis for the reconstruction of the vegetation history of the northern Apennines, although only two of three sequences cover the Late-glacial. Recent geochemical analysis on Prato Spilla C detected the presence of micro-tephra particles in the basal part of the sequence, showing a close correspondence with the Neapolitan Yellow Tephra (NYT) (Davies et al. 2002). The presence of the NYT dates this sequence back to at least 14000 cal B.P. (12000 B.P., Davies et al. 2002). The pollen records from Prato Spilla $C$ and D provide strong evidence for the presence of coniferous and deciduous woodlands in the northern Apennines during the Bølling-Allerød period (ca. 14600-12650 cal B.P., see Vescovi et al. 2007 for a review of northern Italy), even if the thermophilous 
Table 2 Comparison between local pollen zones, bio- and chronostratigraphy from Lago del Greppo and regional pollen zones, bio- and chronostratigraphy from Prato Spilla sites (from Lowe 1992)

\begin{tabular}{|c|c|c|c|c|c|c|}
\hline $\begin{array}{l}\text { Chronozone } \\
\text { (yrs cal B.P.) }\end{array}$ & $\begin{array}{l}\text { Local Pollen Zones } \\
\text { Lago del Greppo }\end{array}$ & ${ }^{14} \mathrm{C}$ dates & $\begin{array}{l}\text { Generalized } \\
\text { time scale } \\
\text { (yrs cal B.P.) }\end{array}$ & \begin{tabular}{|l} 
Regional Pollen Zones \\
(Local Pollen Zones, Prato Spilla)
\end{tabular} & ${ }^{14} \mathrm{C}$ dates & $\begin{array}{l}\text { Generalized } \\
\text { time scale } \\
\text { (yrs cal B.P.) }\end{array}$ \\
\hline Holocene & $\begin{array}{l}\text { LG-6 (0-89 cm) } \\
\text { Fagus-Abies-Picea-(Alnus) } \\
\text { LG-5 }(89-140 \mathrm{~cm}) \\
\text { Fagus-Abies-Picea- QM (Alnus) } \\
\text { LG-4 (140-285 cm) } \\
\text { Abies- Picea-QM } \\
\text { LG-3 (285-299 cm) } \\
\text { Quercus-Betula-Fraxinus-Corylus }\end{array}$ & $\begin{array}{l}6600 \pm 50 \\
6990 \pm 40 \\
7010 \pm 40 \\
7660 \pm 40 \\
7860 \pm 50 \\
8900 \pm 50\end{array}$ & $\begin{array}{l}2200 \text { to present } \\
6500-2200\end{array}$ & $\begin{array}{l}\text { Ap Pm } 8 \text { (PSp A-8, PSp A-7), significantly } \\
\text { reduced woodland cover: anthropogenic } \\
\text { landscape; scattered Fagus and Quercus woods } \\
\text { Ap Pm } 7 \text { (PSp A-6, PSp A-5, PSp C-7) } \\
\text { Fagus-Abies-Quercus (Almus) } \\
\text { Ap Pm } 6 \text { (PSp A-4, PSp C-6) } \\
\text { Abies-Quercus } \\
\text { Ap Pm } 5 \text { (PSp A-3, PSp A-2, PSp C-5) } \\
\text { Abies-Quercus-Ulmus }\end{array}$ & $\begin{array}{l}3890 \pm 45 \\
3300 \pm 45 \\
3535 \pm 40 \\
5035 \pm 50 \\
7345 \pm 45 \\
7965 \pm 45\end{array}$ & $\begin{array}{l}4460-2000 \\
8260-4460 \\
12150-8260\end{array}$ \\
\hline \multicolumn{7}{|c|}{\begin{tabular}{|l}
11500 Late-glacial/Holocene transition \\
\end{tabular}} \\
\hline \begin{tabular}{|l|} 
Younger \\
Dryas \\
\end{tabular} & $?$ & & & \begin{tabular}{|l} 
Ap Pm 3 (PSp C-3) \\
Pinus-Abies-herb association \\
\end{tabular} & $11545 \pm 70$ & $13530-12530$ \\
\hline \multicolumn{7}{|l|}{12650} \\
\hline Late-glacial & $\begin{array}{l}\text { LG-2 }(299-321 \mathrm{~cm}) \\
\text { Pinus-Betula-Corylus- Quercus-Salix } \\
\text { LG-1 }(327-332 \mathrm{~cm}) \\
\text { Juniperus-Artemisia-herb association }\end{array}$ & $\begin{array}{l}10940 \pm 60 \\
\text { Not dated }\end{array}$ & $12600->13000$ & $\begin{array}{l}\text { Ap Pm } 2 \text { (PSp C-2) } \\
\text { Abies-Pinus-Quercus-Corylus } \\
\text { Ap Pm } 1 \text { (PSp C-11) } \\
\text { Pinus-Quercus-Compositae }\end{array}$ & $12360 \pm 55$ & $\begin{array}{l}>14440-13530 \\
\text { Not dated }\end{array}$ \\
\hline
\end{tabular}

deciduous taxa such as Tilia and Quercus were probably confined to lower altitudes below $700-800 \mathrm{~m}$ a.s.l. (Table 2; Lowe 1992; Lowe and Watson 1993). Coleopteran evidence from Prato Spilla D also suggests that before the Younger Dryas at ca. 12650 cal B.P., closed woods were already present between ca. 1,200 and 1,600 $\mathrm{m}$ a.s.l., and probably coniferous and deciduous woodlands had become established in the region around $14000 \mathrm{cal}$ в.P. (Ponel and Lowe 1992).

The northern Apennine pollen records suggest that before $13500 \mathrm{cal}$ B.P., Pinus and Abies were the most important trees which were spreading at Prato Spilla, whereas Pinus, Betula and Picea probably formed the early woods in the Lagdei and Berceto areas. Changes in the woodland structure were probably related to climatic warming at the beginning of the Bølling-Allerød period (Björck et al. 1998; von Grafenstein et al. 1999; Lowe 2001; Heiri and Millet 2005). These results are in agreement with numerous studies from the southern Alps (Wick 1996; Tinner et al. 1999; Pini 2002; Finsinger et al. 2006; Vescovi et al. 2007). Of particular interest is that the expansion of thermophilous taxa such as Quercus, Tilia and Ulmus at our new site of Lago del Greppo perfectly matches the expansion of the same taxa in the southern Alps across the Po Plain at ca. 13100 cal B.P. (Vescovi et al. 2007). Some sites in the Insubrian southern Alps in southern Switzerland and northern Italy (for example Balladrum, Hofstetter et al. 2006) also suggest an expansion of Abies alba at the same time, at $13000 \mathrm{cal}$ B.P. during the Bølling-Allerød interstadial, which also matches the northern Apennine record from Lago del Greppo.

\section{Younger Dryas cooling}

The environmental effects of the Younger Dryas cooling are clearly detectable in the palaeo-environmental records of Europe (Ammann et al. 1993; Jones et al. 2004). In the northern Apennines, the signal of the Younger Dryas (ca. $12650-11500$ cal B.P.) is not so clear. According to Bertoldi (1980) and Bertoldi et al. (2007), the Younger Dryas event in the Lagdei sequence corresponds to the peak of the Pinus curve prior to the Holocene mass expansion of Abies, Quercus and other thermophilous trees. Lowe (1992) correlates this part of the Lagdei sequence with the "Lateglacial interstadial" (=Bølling-Allerød) of the Prato Spilla $\mathrm{C}$ record. This (re)interpretation assigns a marked reduction of thermophilous trees such as Quercus, Tilia and 
Ulmus, and a minor increase of Artemisia, to the Younger Dryas event in the Lagdei I (Bertoldi 1980) and Prato Spilla C and D sequences (Lowe 1992; Lowe and Watson 1993). Such a vegetational change also occurred at Lago del Greppo where it is dated at ca. 12600-12100 cal в.P., that is, in the Younger Dryas and accompanied by a decrease of arboreal pollen (AP) (Fig. 4). However, the ${ }^{14} \mathrm{C}$ dates from Prato Spilla A and C, and to a minor extent also from Prato Spilla D (Lowe and Watson 1993) appear too old, since the vegetational oscillation with a decline of thermophilous trees and expansion of Artemisia in these sequences is radiocarbon dated respectively before 12100 cal B.P. and between 13380 and 12500 cal B.P. $(11545 \pm 70,10500 \pm 55,10300 \pm 45$ uncal B.P., that is, during the Bølling-Allerød interstadial). One possible explanation for this discrepancy might be that the bulk gyttja radiocarbon dates from Prato Spilla basin are affected by reservoir or hard-water effects and are therefore older than suggested by the original authors (Ravazzi 2002). Such an explanation seems in agreement with the presence of the NYT tephra of 13900 cal B.P. at the base of Prato Spilla C, which is later than the oldest radiocarbon date from bulk gyttja (14330 cal в.P.) situated ca. $30 \mathrm{~cm}$ above the NYT. Another possible cause of the debate might be the presence of hiatuses in the sedimentary sequences or a very low depositional rate during the Younger Dryas. In the record of Lago del Greppo, the Younger Dryas is also represented by only a few centimetres (Fig. 4). We feel that new high-precision terrestrial macrofossil dated records are needed to better address the existing uncertainties that have caused this controversy.

Despite chronological problems that affect the records of the northern Apennines, vegetational changes during the Younger Dryas cooling are consistent with various highprecision and resolution studies from northern Italy and especially the southern Alps. In this neighbouring region across the Po Plain, the woodland cover diminished, thermophilous taxa such as Quercus and Tilia declined, and herbaceous taxa re-expanded together with cold-adapted trees such as Pinus cembra and Larix, and heliophilous trees such as Betula (Schneider and Tobolski 1985; Wick 1996; Tinner et al. 1999; Pini 2002; Finsinger et al. 2006). In spite of this cooling, the treeline in the southern Alps was still around 1,500-1,800 $\mathrm{m}$ a.s.l. (Gobet et al. 2005; Vescovi et al. 2007). Further south, in central Italy the Younger Dryas also caused a collapse of thermophilous woodland, as seen for example in the depression of the Quercus pollen curves at Lagaccione and Lago Grande di Monticchio (Magri 1999; Huntley et al. 1999). In this latter region the Younger Dryas cooling seems to be characterized by two contrasting hydrological patterns: the first period before ca. $12150 \mathrm{cal}$ B.P. with generally wetter conditions, and the second half with progressively drier conditions (Drescher-Schneider et al. 2007; Magny et al. 2006, 2007).

\section{Holocene}

In the northern Apennines thermophilous trees such as Quercus, Ulmus, Tilia, Fraxinus and Corylus expanded abruptly at the onset of the Holocene at 11600-11500 cal B.P. Synchronously, Betula expanded abruptly to decline only a few centuries later. The decline of Betula was accompanied by the re-expansion of Abies at Prato Spilla A and C and at Lago Padule (Lowe 1992; Watson 1996) or expansion as at Lago del Greppo and at Lagdei (Bertoldi et al. 2007). The transient and marked expansion of Betula and the expansion or re-expansion of Abies are characteristic for the region, even if in different proportions in the various sequences. These early Holocene vegetational changes were most probably a consequence of climatic change between ca. 11600 and 9500 cal B.P. At the Lateglacial/Holocene transition at ca. 11600 cal B.P., temperatures increased by about $3-4^{\circ} \mathrm{C}$ within a few decades in central Europe and the Alps (Ammann et al. 2000; von Grafenstein et al. 2000; Schwander et al. 2000). After 11500 cal B.P., temperatures increased more gradually by a further $2-3.5^{\circ} \mathrm{C}$ until $9800-9600$ cal B.P. (Tinner and Kaltenrieder 2005). Rapid environmental responses to early Holocene drastic climatic warming are recorded in many high resolution and precision studies from Europe (Birks and Ammann 2000; Vescovi et al. 2007) and include drastic vegetation changes such as tree line upslope migration by about $800 \mathrm{~m}$ in a few centuries (Tinner and Kaltenrieder 2005).

Pollen records from the region suggest that between ca. 9500 and 6000 cal B.P. woods became very dense and were characterized by an upper belt dominated by Abies alba together with other tree taxa such as Picea abies, Quercus, Tilia, Ulmus and Acer. At lower elevations the forests were most probably co-dominated by Abies, Quercus, Acer, Tilia, Ulmus and Fraxinus. This amazing dominance or codominance of Abies alba in the forests of the northern Apennines had become established by ca. 10500 cal B.P. and persisted for more than 5,000 years, until ca. $5000 \mathrm{cal}$ B.P. It strikingly matches the records from the Insubrian southern Alps in southern Switzerland and northern Italy which show that Abies alba dominated or co-dominated the forests there from the plains up to the treeline during the period 10500-5000 cal B.P. (Tinner et al. 1999; Gobet et al. 2000).

In the mid Holocene, Fagus expanded markedly between 6500 cal B.P. (Lago Pratignano, Watson 1996; Lago del Greppo) and ca. 3500 cal B.P. (Lago delle Lame, Lago Nero, Cruise 1990a). At most sites in the montane belt of the northern Apennines, the rise of Fagus followed 
or was at the same time as the decline of Abies, while below 800-900 m a.s.1. Quercus replaced Abies (Pavullo and Bargone; Bertolani Marchetti et al. 1994; Cruise 1990a; Vescovi 2007). This process was probably not synchronous in the region. The pollen records suggest that Fagus established conspicuous populations at around 6000-5000 cal B.P. in the eastern part of the northern Apennines and at ca. 4500-3000 cal B.P. in the western part (Cruise 1990a; Watson 1996), but these estimates mainly rely on dates from bulk samples that are often chronologically imprecise.

The reason for the collapse of Abies and the population expansion of Fagus in the northern Apennines is not yet really understood. The influence of climatic change, human impact including fire, a combination of both, or other factors have been invoked to explain the Holocene behaviour of these two taxa (Cruise 1990b; Lowe et al. 1994a, b). Watson (1996) showed that in seven of 16 sites that she examined, for example Casanova and Prato Mollo (Cruise 1990a), organic sedimentation started during the Holocene (ca. 5800 cal B.P.) or restarted again after an early Holocene hiatus (for example at Prato Mollo) suggesting that the climatic conditions became wetter during the mid and late Holocene. On the other hand, we have to consider regional variations, which may be connected to different climatic conditions from east to west along the chain. Watson (1996) suggests that the most significant influence on the vegetation of the region was climatic change, but the temporal resolution and precision of the northern Apennines records are not sufficient to address this hypothesis thoroughly, by comparison with independent palaeo-climatic series. In southern central Europe, new records support the climatic hypothesis regarding the early Holocene population expansions of Fagus there (Tinner and Lotter 2001, 2006). However, Fagus and Abies expansions occurred there much earlier at 8200 cal B.P., before the onset of the Neolithic, and are considered to be the result of a fully natural process.

It has also been suggested that the population expansion of Fagus in the northern Apennines was a result of forest disturbance by humans (Lowe 1992; Lowe et al. 1994a, b). Unfortunately, in most of the records from the northern Apennines, pollen percentages of the taxa associated with cultivation or pastoralism are often too low or the taxonomic precision is not great enough to allow accurate assessment of this hypothesis. Moreover, no evidence of fire disturbance is yet available for the area. Our new microcharcoal record of Lago del Greppo indeed shows that the relevance of fire increased around 6500 cal B.P., probably in connection with Neolithic human impact that probably contributed to the marked vegetational change. Because Fagus seedlings require moderate light intensity for development, the dense Abies forest, which had already become established at the onset of the Holocene in the Apennines, probably tended to hamper the development of Fagus through shading (Ellenberg 1986). After disturbance of the forests, Fagus may have attained dominance. In agreement, archaeological evidence suggests an increase of human activities in Valle del Serchio, northern Toscana, during the late Neolithic and the beginning of the metal ages with unambiguous traces of human activities below $500 \mathrm{~m}$ a.s.l. and above $1,500 \mathrm{~m}$ a.s.l. (Castelletti et al. 1994). In the Ligurian Apennines, a level of macro-charcoal at the base of the Pramollo pollen sequences, which was related to a find of Chalcolithic flints, seems to indicate human activities or disturbances between 5500 and 5000 cal B.P. (Lowe et al. 1994a). Similar indications come from the record of Lago Nero and support the hypothesis of human-triggered shift from Abies to Fagus and Quercus forests (Lowe et al. 1994a). Again very similar vegetational dynamics occurred in the Insubrian southern Alps and northern Italy where the collapse of Abies alba and the expansion of F. sylvatica and Quercus at around $5000 \mathrm{cal}$ B.P. has been mainly attributed to fire and human impact (Tinner et al. 1999; Gobet et al. 2000; Keller et al. 2002). Strikingly, similar fire and human-induced collapses of Abies alba communities have been also found in the Mediterranean vegetation belt south of the northern Apennines (Colombaroli et al. 2007). There, Quercus ilex (holm oak) and other maquis-forming Mediterranean taxa expanded at the cost of Abies alba. Where Abies was not dominant or co-dominant before the expansion of Fagus, as in more continental northern Italy, combined effects of climate change, fire and human impact seem to have caused the expansion of Fagus (Valsecchi et al. 2008).

During the late Holocene, Fagus continued to dominate the woodland vegetation in the northern Apennines at Lago delle Lame, Prato Spilla and Lago Padule, with only a slight opening of the woods (Cruise 1990a; Lowe 1992; Watson 1996). A clearer sign of opening at Agoraie, Casanova, Lago Pratignano and Lago del Greppo is evident only during the Roman period (Cruise 1990b; Watson 1996). Typical crops of the Roman period such as Olea, Castanea and Juglans (Gobet et al. 2000; Branch 2004) are uncommon in the analyzed sequences, the only sites consistently recording their presence in the area are Lago del Greppo, Pavullo nel Frignano and Bargone (Cruise 1990a; Vescovi 2007). Usually the sites analyzed in the northern Apennines are above $1,000 \mathrm{~m}$, and the late Holocene lack of intense human activity may primarily result from low intensity land use at this elevation.

\section{Picea abies in the northern Apennines}

The present distribution of Picea in the northern Apennines is limited to two small relict areas near the divide between 
Emilia and Toscana. One small population is located exactly in the high Valle del Sestaione near Passo dell'Abetone, close Lago del Greppo. At the onset of the Holocene, boreal or subalpine Picea probably moved upwards, in response to climatic warming and competition from other more thermophilous trees such as Abies. Today it is present only in the highest and coldest part of the mountain range at a few favourable sites, and has become extinct elsewhere. This situation differs very much from the situation in the Alps, where higher elevations allowed Picea abies to spread successfully during the Holocene (Ravazzi 2002).

During the Alpine deglaciation at $18000-14500$ cal B.P., populations of Picea abies contracted and probably survived in the lowlands and the low foothills (Ravazzi 2002) in and around the Apennines. Chiarugi (1936b) suggested that Picea probably survived the Last Glacial Maximum (LGM) in the northern Apennines. Several other studies seem to support this hypothesis (Chiarugi 1936b, 1958). Bertoldi (1980) reported continuous curves of Picea pollen in the pollen record of Lagdei during the Late-glacial and the early Holocene until ca. $11350 \mathrm{cal}$ в.P. (Bertoldi et al. 2007). Other evidence of the presence of Picea during the LGM and Late-glacial are scattered along the northern side of the Apennines and the border of the Po plain. Considering this evidence, Ravazzi (2002) supports the hypothesis of a main refugium of Picea in the Apennines that is almost neglected in more central or northern European studies (Huntley and Birks 1983; Terhürne-Berson 2005; Latałowa and van der Knaap 2006).

Recent finds of spruce cones and needles in the Apennine foothills at Bubano quarry (12.5 m a.s.l.) near Imola support the original idea of Chiarugi of an important Picea refugium in the northern Apennines (Ravazzi et al. 2006). These macrofossils prove the presence of Picea in Pinus sylvestris-Betula dominated woods in the northern Apennine region before and during the Bølling-Allerød interstadial (ca. 14800 cal в.P.). In addition, data from Pavullo nel Frignano (675 m a.s.l.), a site in the Apennine foothills near Modena, show the presence of an almost continuous curve of Picea pollen after ca. 13900 cal в.P. (Vescovi 2007). However, pollen and stomata evidence from Lago del Greppo (1,442 m a.s.l.) shows that spruce was certainly present in situ from $11000 \mathrm{cal}$ B.P. onwards, although low values of Picea pollen are also recorded before $13000 \mathrm{cal}$ B.P. Scattered evidence of the presence of Picea in the northern Apennines during the Holocene is recorded in the pollen records of the Prato Spilla A, Casanova, Fociomboli, and Lama Lite (Braggio Morucchio et al. 1980; Cruise 1990a, b; Lowe 1992; Lowe and Watson 1993; Ravazzi et al. 2006).

Genetic data from modern Picea abies populations (Tollefsrud et al. 2008) might not be useful to clarify the relevance of the northern Apennines Glacial and Lateglacial refugia. In fact, almost all Glacial and Late-glacial populations in the northern Apennines became extinct at the onset of the Holocene, when the climate became warmer. Thus, most of the genetic varieties of these ancient southern populations did not persist locally until now, although they might have considerably contributed to the constitution of modern populations elsewhere in Europe. Palaeogenetic analyses may prove to be very helpful in elucidating this issue, but are completely lacking so far for the southern European spruce populations.

\section{Conclusions}

Despite its crucial position between well-studied sites in northern Italy, Italian southern Switzerland (Schneider and Tobolski 1985; Wick 1996; Tinner et al. 1999; Pini 2002; Finsinger et al. 2006) and central and southern Italy (Huntley et al. 1999; Magri 1999), modern palaeoecological and palaeobotanical investigations in the northern Apennines are still rare. Our new study from Lago del Greppo provides new high-resolution and precision pollen and charcoal records covering the past 13,000 years. Despite interesting differences for important taxa along the Apennine chain such as Picea and Abies, the general patterns of vegetation history are consistent. Nevertheless, additional pollen, macrofossil, and charcoal stratigraphies from the northern Apennines are urgently needed to close the gaps in the spatial coverage of palaeoecological data, to improve radiocarbon chronologies, and to refine our knowledge about vegetational history of this region, which is a biogeographically important area at the border between northern and central Italy. Our new study reveals striking correlations between the Insubrian southern Alps and the northern Apennines, two areas which are separated by the Po Plain. This close link persisted from the Late-glacial throughout the Holocene and is best characterised by the early and strong relevance of Abies alba across different vegetational belts. These similarities are best explained by similar climatic forcing that must have persisted for millennia. Taken together, our data suggest that the isolated remnant stands of Picea abies in the northern Apennines have a history of at least 13,000 years. Their preservation is therefore mandatory, also to guarantee the genetic diversity of this important European tree.

Acknowledgements We are grateful to the participants to the XXX International Moor Excursion that visited the site in 2006 for fruitful discussions and useful suggestions and especially for the advice of $F$. Bittmann for improving the Late-glacial chronology. M. Donegana, G. Tanzi, L. Pacifico, H.E. Wright, Willi and Mike Tanner are gratefully acknowledged for help during coring and F. Oberli for laboratory assistance. Improvements to the manuscript by H.E. Wright and two anonymous reviewers are grateful acknowledged. We 
are grateful to Swiss National Science Foundation, which financed this study (SNF Nr3100A0-101218) and to Corpo Forestale dello Stato-Ufficio Territoriale per la Biodiversità di Pistoia and "le Guardie forestali del Posto Fisso dell'Abetone" for the permission and for assistance during the coring.

\section{References}

Ammann B, Birks HJB, Drescher-Schneider R, Juggins S, Lang G, Lotter AF (1993) Patterns of variation in Late-glacial pollen stratigraphy along a Northwest-Southeast transect through Switzerland-a numerical analysis. Quat Sci Rev 12:277-286

Ammann B, Birks HJB, Brooks SJ, Eicher U, von Grafenstein U, Hofmann W, Lemdahl G, Schwander J, Tobolski K, Wick L (2000) Quantification of biotic responses to rapid climatic changes around the Younger Dryas-a synthesis. Palaeogeogr Palaeoclimatol Palaeoecol 159:313-347

Bennett KD (1996) Determination of the number of zones in a biostratigraphical sequence. New Phytol 132:155-170

Bertolani Marchetti D, Accorsi CA, Bandini Mazzanti M, Dallai D, Forlani L, Mariotti Lippi M, Mercuri AM, Mori M, Rivalenti C, Trevisan Grandi G (1994) Palynological diagram of the peat-bog near Pavullo nel Frignano (Modena, Italy) in the framework of Tuscan/Emilian Apennines vegetation history. Hist Biol 9:91-101

Bertoldi R (1980) Le vicende vegetazionali e climatiche nella sequenza paleobotanica wurmiana e post-wurmiana di Lagdei (Appennino settentrionale). Ateneo Parmense Acta Nat 16:147_ 175

Bertoldi R, Chelli A, Roma R, Tellini C, Vescovi P (2004) First remarks on Late Pleistocene lacustrine deposits in the Berceto area (Northern Apennines, Italy). Il Quaternario 17:133-143

Bertoldi R, Chelli A, Roma R, Tellini C (2007) New data from Northern Apennines (Italy) pollen sequences spanninng the last 30,000 yrs. Il Quaternario 20:3-20

Beug H-J (2004) Leitfaden der Pollenbestimmung für Mitteleuropa und angrenzende Gebiete. Pfeil, München

Birks HH, Ammann B (2000) Two terrestrial records of rapid climatic change during the glacial-Holocene transition (14,000-9,000 calendar years B.P.) from Europe. Proc Natl Acad Sci 97:13901394

Birks HJB, Gordon AD (1985) Numerical methods in Quaternary pollen analysis. Academic Press, London

Birks HJB, Line JM (1992) The use of rarefaction analysis for estimating palynological richness from Quaternary pollen-analytical data. Holocene 2:1-10

Björck S, Walker MJC, Cwynar LC, Johnsen S, Knudesen K-L, Lowe JJ, Wohlfarth B, INTIMATE members (1998) An event stratigraphy for the Last Termination in the North Atlantic region based on the Greenland ice-core record: a proposal by the INTIMATE group. J Quat Sci 13:283-292

Braggio Morucchio G, Guido AM (1975) Analisi palinologica dei depositi lacustri postglaciali del Lago delle Agoraie di Mezzo. Archivio Botanico e Biogeografico Italiano 20:48-73

Braggio Morucchio G, Guido AM, Montanari C (1978) Studio palinologico e vegetazionale della torbiera del Lajone presso Pianpaludo (Gruppo M.Beigua, Appennino ligure occidentale). Archivio Botanico e Biogeografico Italiano 54:115-136

Braggio Morucchio G, Guido AM, Monatanari C (1980) Studio palinologico dei sedimenti postglaciali dei Fociomboli (Alpi Apuane). Atti Soc Tosc Sci Nat Mem Serie B 87:220-227

Branch N (2004) Late Würm Lateglacial and Holocene environmental history of the Ligurian Apennines, Italy. In: Balzaretti R, Pearce M, Watkins C (eds) Ligurian landscapes: studies in archaeology, geography and history in memory of Edoardo Grendi, vol 10. Accordia Research Institute, pp 7-69

Castelletti L, Maspero A, Tozzi C (1994) Il popolamento della Valle del Serchio (Toscana Settentrionale) durante il Tardiglaciale Wurmiano e l'Olocene antico. In: Biagi P, Nandris J (eds) Highland zone exploitation in southern Europe, vol 20. Monografie di Natura Bresciana, Brescia, pp 189-204

Chiarugi A (1936a) Ricerche sulla vegetazione dell'Etruria Marittima I.-Cicli forestali Postglaciali nell'Appennino Etrusco attraverso l'analisi pollinica di torbe e depositi lacustri presso L'Alpe delle Tre Potenze e il M. Rondinaio. Nuovo Giornale Botanico Italiano, n.s. 63:3-61

Chiarugi A (1936b) Ricerche sulla vegetazione dell'Etruria Marittima III.-L'indigenato della "Picea excelsa" Lk. nell'Appennino Etrusco. Nuovo Giornale Botanico Italiano, n.s. 63:131-166

Chiarugi A (1958) Ricerche sulla vegetazione dell'Etruria Marittima. XI: Una seconda aera relitta di vegetazione spontanea di pigella (Picea excelsa LK.) sull'Appennino settentrionale. Nuovo Giornale Botanico Italiano 65:23-41

Colombaroli D, Marchetto A, Tinner W (2007) Long-term interactions between Mediterranean climate, vegetation and fire regime at Lago di Massaciuccoli (Tuscany, Italy). J Ecol 95:755-770

Cruise GM (1990a) Holocene peat initiation in the Ligurian Apennines, northern Italy. Rev Palaeobot Palynol 63:173-182

Cruise GM (1990b) Pollen stratigraphy of two Holocene peat sites in the Ligurian Apennines, northern Italy. Rev Palaeobot Palynol 63:299-313

Davies SM, Branch NP, Lowe JJ, Turney CSM (2002) Towards a European tephrochronological framework for Termination 1 and Early Holocene. Philos Trans R Soc Lond A 360:767-802

De Stefani C (1883) I laghi dell'Appennino Settentrionale. Bollettino del CAI 17:1-99

Drescher-Schneider R, de Beaulieu JL, Magny M (2007) Vegetation history climate and human impact over the last 15,000 years at Lago dell'Accesa (Tuscany, Central Italy). Veget Hist Archaeobot 16:279-299

Ellenberg H (1986) Vegetation Mitteleuropas mit den Alpen in ökologischer Sicht, 4th edn. Ulmer, Stuttgart

Finsinger W, Tinner W (2005) Minimum count sums for charcoalconcentration estimates in pollen slides: accuracy and potential errors. Holocene 15:293-297

Finsinger W, Tinner W, van der Knaap WO, Ammann B (2006) The expansion of hazel (Corylus avellana L.) in the southern Alps: a key for understanding its early Holocene history in Europe? Quat Sci Rev 25:612-631

Gobet E, Tinner W, Hubschmid P, Jansen I, Wehrli M, Ammann B, Wick L (2000) Influence of human impact and bedrock differences on the vegetational history of the Insubrian Southern Alps. Veget Hist Archaeobot 9:175-187

Gobet E, Tinner W, Bigler C, Hochuli PA, Ammann B (2005) EarlyHolocene afforestation processes in the lower subalpine belt of the Central Swiss Alps as inferred from macrofossil and pollen records. Holocene 15:672-686

Grimm E (1992-2005) Tilia version 2.0.2 and TiliaGraph 1.12. Illinois State Museum, Research and Collection Centre

Heegaard E, Birks HJB, Telford RJ (2005) Relationships between calibrated ages and depth in stratigraphical sequences: an estimation procedure by mixed-effect regression. Holocene 15:612-618

Heiri O, Millet L (2005) Reconstruction of Late Glacial summer temperatures from chironomid assemblages in Lac Lautrey (Jura, France). J Quat Sci 20:33-44

Heiri O, Lotter AF, Lemcke G (2001) Loss on ignition as a method for estimating organic and carbonate content in sediment: reproducibility and comparability of results. J Paleolimnol 25:101-110 
Hill MO (1979) DECORANA: a FORTRAN program for detrended correspondence analysis and reciprocal averaging. Cornell University, Ithaca, NY

Hofstetter S, Tinner W, Valsecchi V, Carraro G, Conedera M (2006) Lateglacial and Holocene vegetation history in the Insubrian Southern Alps-new indications from a small-scale site. Veget Hist Archaeobot 15:87-98

Huntley B, Birks HJB (1983) An atlas of past and present maps for Europe: 0-13000 years ago. Cambridge University Press, Cambridge

Huntley B, Watts WA, Allen JRM, Zolitschka B (1999) Palaeoclimate, chronology and vegetation history of the Weichselian Lateglacial: comparative analysis of data from three cores at Lago Grande di Monticchio, southern Italy. Quat Sci Rev 18:945-960

Jaurand E (1998) Les glaciers disparus de l'Apennin: Geomorphologie et paleoenvironnements glaciaires de l'Italie peninsulaire. Publication de la Sorbonne, Paris

Jones RL, O'Brien CE, Cooper GR (2004) Palaeoenvironmental reconstruction of the Younger Dryas in Jersey, UK Channel Islands, based on plant and insect fossils. Proc Geol Assoc 115:43-53

Kaltenrieder P, Belis CA, Hofstetter S, Ammann B, Ravazzi C, Tinner W (2009) Environmental and climatic conditions at a potential Glacial refugial site of tree species near the Southern Alpine glaciers. New insights from multiproxy sedimentary studies at Lago della Costa (Euganean Hills, Northeastern Italy). Quat Sci Rev 28:2647-2662

Keller F, Lischke H, Mathis T, Möhl A, Wick L, Ammann B, Kienast F (2002) Effects of climate, fire, and humans on forest dynamics: forest simulations compared to the palaeological record. Ecol Model 152:109-127

Latałowa M, van der Knaap WO (2006) Late Quaternary expansion of Norway spruce Picea abies (Karst.) in Europe according to pollen data. Quat Sci Rev 25:2780-2805

Lowe JJ (1992) Lateglacial and early Holocene lake sediments from the northern Apennines, Italy-pollen stratigraphy and radiocarbon dating. Boreas 21:193-208

Lowe JJ (2001) Abrupt climatic changes in Europe during the last glacial-interglacial transition: the potential for testing hypotheses on the synchroneity of climatic events using tephrochronology. Global Planet Change 30:73-84

Lowe JJ, Watson C (1993) Lateglacial and early Holocene pollen stratigraphy of the Northern Apennines, Italy. Quat Sci Rev 12:727-738

Lowe JJ, Branch N, Watson C (1994a) The chronology of human disturbance of the vegetation of the Northern Apennines during the Holocene. In: Biagi P, Nandris J (eds) Highland zone exploitation in southern Europe, vol 20. Monografie di Natura Bresciana, Brescia, pp 169-187

Lowe JJ, Davite C, Moreno D, Maggi R (1994b) Holocene pollen stratigraphy and human interference in the woodlands of the Northern Apennines, Italy. Holocene 4:153-164

Magny M, de Beaulieu J-L, Drescher-Schneider R, Vannière B, Walter-Simonnet A-V, Millet L, Bossuet G, Peyron O (2006) Climatic oscillations in central Italy during the Last GlacialHolocene transition: the record from Lake Accesa. J Quat Sci 21:311-320

Magny M, de Beaulieu J-L, Drescher-Schneider R, Vannière B, Walter-Simonnet A-V, Miras Y, Millet L, Bossuet G, Peyron O, Brugiapaglia E, Leroux A (2007) Holocene climate changes in the central Mediterranean as recorded by lake-level fluctuations at Lake Accesa (Tuscany, Italy). Quat Sci Rev 26:1736-1758

Magri D (1999) Late Quaternary vegetation history at Lagaccione near Bolsena (Central Italy). Rev Palaeobot Palynol 106:171208
Merkt J, Streif H (1970) Stechrohr-Bohrgeräte für limnische und marine Lockersedimente. Geol Jahrb 88:137-148

Moore PD, Webb JA, Collinson ME (1991) Pollen analysis, 2nd edn. Oxford, Blackwell

Mori Secci M (1996) Vicende oloceniche dell'Appennino ToscoEmiliano ricostruite attraverso le analisi palinologiche. Webbia $51: 83-120$

Odgaard BV (1999) Fossil pollen as a record of past biodiversity. J Biogeogr 26:7-17

Pini R (2002) A high-resolution Late-glacial-Holocene pollen diagram from Pian di Gembro (Central Alps, Northern Italy). Veget Hist Archaeobot 11:251-262

Pinna M (1977) Climatologia. Unione Tipografico-Editrice Torinese, Torino

Ponel P, Lowe JJ (1992) Coleopteran, pollen and radiocarbon evidence from the Prato Spilla "D" succession, N. Italy. CR Acad Sci Paris 315:1425-1431

Punt W, Blackmore S (1976-2003) The northwest European Pollen Flora, vol 8. Elsevier, Amsterdam

Ravazzi C (2002) Late Quaternary history of spruce in southern Europe. Rev Palaeobot Palynol 120:131-177

Ravazzi C, Donegana M, Vescovi E, Arpenti E, Caccianiga M, Kaltenrieder P, Londeix L, Marabini S, Mariani S, Pini R, Vai GB, Wick L (2006) A new Lateglacial site with Picea abies in the Northern Apennine foothills: a population failing the model of glacial refugia trees. Veget Hist Archaeobot 15:357-371

Reille M (1992-1998) Pollen et spores d'Europe et d'Afrique du Nord. Marseille. Laboratoire de botanique historique et palynologie

Reimer PJ, Baillie MGL, Bard E, Bayliss A, Beck JW, Bertrand C, Blackwell PG, Buck CE, Burr G, Cutler KB, Damon PE, Edwards RL, Fairbanks RG, Friedrich M, Guilderson TP, Hughen KA, Kromer B, McCormac FG, Manning S, Bronk Ramsey C, Reimer RW, Remmele S, Southon JR, Stuiver M, Talamo S, Taylor FW, Van der Plicht J, Weyhenmeyer CE (2004) IntCal04 terrestrial radiocarbon age calibration, 0-26 cal kyr BP. Radiocarbon 46:1029-1058

Schneider R, Tobolski K (1985) Lago di Ganna-Late-glacial and Holocene environments of a Lake in the Southern Alps. Diss Bot 87:229-271

Schwander J, Eicher U, Ammann B (2000) Oxygen isotopes of lake marl at Gerzensee and Leysin (Switzerland), covering the Younger Dryas and two minor oscillations, and their correlation to the GRIP ice core. Palaeogeogr Palaeoclimatol Palaeoecol 159:203-214

Scotti I, Vendramin GG, Matteotti S, Scarponi C, Sari-Gorla M, Binelli G (2000) Postglacial recolonization routes for Picea abies K. in Italy as suggested by the analysis of sequencecharacterized amplified region (SCAR) markers. Mol Ecol 9:699-708

Stockmarr J (1971) Tablets with spores used in absolute pollen analysis. Pollen Spores 13:615-621

Terhürne-Berson R (2005) Changing distribution patterns of selected conifers in the Quaternary of Europe caused by climatic variations. Doctoral thesis, University of Bonn

Tinner W, Hu FS (2003) Size parameters, size-class distribution and area-number relationship of microscopic charcoal: relevance for fire reconstruction. Holocene 13:499-505

Tinner W, Kaltenrieder P (2005) Rapid responses of high-mountain vegetation to early Holocene environmental changes in the Swiss Alps. J Ecol 93:936-947

Tinner W, Lotter AF (2001) Central European vegetation response to abrupt climate change at $8.2 \mathrm{ka}$. Geology 29:551-554

Tinner W, Lotter AF (2006) Holocene expansions of Fagus silvatica and Abies alba in Central Europe: Where are we after eight decades of debate? Quat Sci Rev 25:526-549 
Tinner W, Vescovi E (2007) Ecologia e oscillazioni del limite degli alberi nelle Alpi dal Pleniglaciale al presente. In: Frisia S, Filippi ML, Borsato A (ed) Cambiamenti climatici e ambientali in Trentino: dal passato prospettive per il futuro. Studi Trentini di Scienze Naturali, Acta Geolog 82:5-13

Tinner W, Hubschmid P, Wehrli M, Ammann B, Conedera M (1999) Long-term forest fire ecology and dynamics in southern Switzerland. J Ecol 87:273-289

Tollefsrud MM, Kissling R, Gugerli F, Johnsen O, Skroppa T, Cheddadi R, Van der Knaap WO, Latałowa M, Terhürne-Berson R, Litt T, Geburek T, Brochmann C, Sperisen C (2008) Genetic consequences of glacial survival and postglacial colonization in Norway spruce: combined analysis of mitochondrial DNA and fossil pollen. Mol Ecol 17:4134-4150

Trautmann W (1953) Zur Unterscheidung fossiler Spaltöffnungen der mitteleuropäischen Coniferen. Flora 140:523-533

Valsecchi V, Finsinger W, Tinner W, Ammann B (2008) Testing the influence of climate, human impact and fire on the Holocene population expansion of Fagus sylvatica in the southern Prealps (Italy). Holocene 18:603-614

Vendramin GG, Anzidei M, Madaghiele A, Sperisen C, Bucci G (2000) Chloroplast microsatellite analysis reveals the presence of population subdivision in Norway spruce (Picea abies K.). Genome 43:68-78

Vescovi E (2007) Long-term population dynamics of major forest trees under strongly changing climatic conditions. Doctoral thesis, University of Bern
Vescovi E, Ravazzi C, Arpenti E, Finsinger W, Pini R, Valsecchi V, Wick L, Ammann B, Tinner W (2007) Interactions between climate and vegetation during the Lateglacial period as recorded by lake and mire sediment archives in Northern Italy and Southern Switzerland. Quat Sci Rev 26:1650-1669

von Grafenstein U, Erlenkeuser H, Brauer A, Jouzel J, Johnsen SJ (1999) A mid-European decadal isotope-climate record from 15,500 to 5000 years BP. Science 284:1654-1657

von Grafenstein U, Eicher U, Erlenkeuser H, Ruch P, Schwander J, Ammann B (2000) Isotope signature of the Younger Dryas and two minor oscillations at Gerzensee (Switzerland): palaeoclimatic and palaeolimnologic interpretation based on bulk and biogenic carbonates. Palaeogeogr Palaeoclimatol Palaeoecol 159:215-229

Watson C (1996) The vegetation history of the northern Apennines, Italy: information from three new sequences and a review of regional vegetational change. J Biogeogr 23:805-841

Watson C, Branch N, Lowe JJ (1994) The vegetation history of the northern Apennines during the Holocene. In: Biagi P, Nandris J (eds) Highland zone exploitation in southern Europe, vol 20. Monografie di Natura Bresciana, Brescia, pp 153-168

Wick L (1996) Late-glacial and early-Holocene palaeoenvironments in Brianza, N Italy. Il Quaternario 9:653-660 